\title{
Morphology of coronary artery lesions assessed by virtual histology intravascular ultrasound tissue characterization and fractional flow reserve
}

\author{
Salvatore Brugaletta $\cdot$ Hector M. Garcia-Garcia - Zhu Jun Shen • \\ Josep Gomez-Lara • Roberto Diletti • Giovanna Sarno • Nieves Gonzalo • \\ William Wijns • Bernard de Bruyne $\cdot$ Fernando Alfonso $\cdot$ Patrick W. Serruys
}

Received: 19 October 2010/ Accepted: 20 January 2011

(C) Springer Science+Business Media, B.V. 2011

\begin{abstract}
Fractional flow reserve (FFR) is an index of the physiological significance of a coronary stenosis. Patients who have lesions with a FFR of $>0.80$, even optimally treated with medication, have however a MACE rate ranging from 8 to $21 \%$. Coronary plaques at high risk of rupture and clinical events can be also identified by virtual histology intravascular ultrasound (IVUS-VH) as plaques with high amount of necrotic core (NC) abutting the lumen. Aim of this exploratory study was to investigate whether the geometry and composition of lesions with FFR $\leq 0.80$ were different from their counterparts. Fifty-five consecutive patients in whom FFR was clinically indicated on a moderate angiographic
\end{abstract}

S. Brugaletta · H. M. Garcia-Garcia ( $₫)$.

Z. J. Shen · J. Gomez-Lara · R. Diletti ·

G. Sarno - P. W. Serruys

Z120, Thoraxcentre, Erasmus MC, 's-Gravendijkwal 230,

3015 CE Rotterdam, The Netherlands

e-mail: h.garciagarcia@erasmusmc.nl

S. Brugaletta

Department of Cardiology, Thorax Institute,

Hospital Clinic, Barcelona, Spain

H. M. Garcia-Garcia

Cardialysis BV, Rotterdam, The Netherlands

N. Gonzalo · F. Alfonso

Hospital Clinico, Madrid, Spain

W. Wijns - B. de Bruyne

Cardiovascular Center, Aalst, Belgium lesion, received also an imaging investigation on the same lesion with IVUS-VH. Data on plaque geometry and composition was analyzed. Patients were subdivided in two groups according to the value of FFR ( $>$ or $\leq 0.80)$. Lesions with a FFR $\leq 0.80 \quad(n=17)$ showed a slightly larger plaque burden than those with FFR $>0.80(n=38)(54.6 \pm 0.7 \%$ vs. $51.7 \pm 0.7 \%$ $P=0.1)$. In addition, they tend to have less content of necrotic core than their counterparts $(14.2 \pm 8 \%$ vs. $19.2 \pm 10.2 \%, P=0.08$ ). No difference was found in the distribution of $\mathrm{NC}$-rich plaques (fibroatheroma and thin-capped fibroatheroma) between groups ( $82 \%$ in FFR $\leq 0.80$ vs. $79 \%$ in FFR $>0.80, P=0.5$ ). Although FFR $\leq 0.80$ lesions have larger plaque size, they do not differ in composition from the ones with FFR $>0.80$. Further exploration in a large prospective study is needed to study whether the lesions with FFR $>0.80$ that are $\mathrm{NC}$ rich are the ones associated with the presence of clinical events at follow-up.

Keywords Intravascular ultrasound virtual histology $\cdot$ Fractional flow reserve

\section{Introduction}

The presence of myocardial ischemia is an important risk factor for an adverse clinical outcome [1]. Revascularization of stenotic coronary lesions that induce ischemia can improve patient's functional 
status and outcome [1, 2]. For stenotic lesions that do not induce ischemia, however, the benefit of revascularization is less clear, and medical therapy alone is likely to be equally effective [3,4].

Fractional flow reserve (FFR) is an index of the physiological significance of a coronary stenosis and is defined as the ratio of maximal blood flow in a stenotic artery to normal maximal flow [5]. A FFR value of 0.80 or less identifies ischemia-causing coronary stenoses with accuracy of more than $90 \%$ $[5,6]$. Plaques at high risk of rupture and provoking coronary events appear to have high amount of necrotic core [7-10] and this feature can be readily identified by virtual histology intravascular ultrasound (IVUS-VH) [11].

Aim of our study was to explore whether the geometry and composition of lesions with FFR $\leq 0.80$ were different from their counterparts.

\section{Methods}

In this exploratory study, all consecutive patients, exhibiting an angiographically moderate lesion on one coronary vessel, admitted from January 2009 to January 2010 in whom FFR was clinically indicated $[12,13]$, underwent on the same lesion an IVUS-VH analysis to investigate the relationship between functional and morphological/compositional lesion characteristics.

\section{Quantitative coronary angiography analysis}

Quantitative coronary angiography (QCA) analyses were performed by one experienced independent observer, blinded to FFR, IVUS-VH and clinical data, using the CAAS II analysis system (Pie Medical BV, Maastricht, Netherlands). The following QCA parameters were computed: computer-defined minimum lumen diameter (MLD), reference vessel diameter (RVD) obtained by the interpolate method, and percentage diameter stenosis [14].

IVUS-VH acquisition and plaque-type classification

The IVUS was performed using the Eagle Eye $20 \mathrm{MHz}$ catheter (Volcano Corp., Rancho Cordova,
California) with an automatic continuous pullback at a rate of $0.5 \mathrm{~mm} / \mathrm{s}$ (30 frames/sec) at level of the lesion evaluated by FFR. Grayscale images and radiofrequency data required for $\mathrm{VH}$ analysis were acquired during the same pullback and raw radiofrequency data capture gated to the $\mathrm{R}$ wave (In-Vision Gold, Volcano). The VH processing was performed offline with pcVH 2.1 software (Volcano Corp., Rancho Cordova, California) that permits semi-automated contours detection and provides the compositional structure of the vessel. Quantitative IVUS measurements included vessel area, lumen area, plaque area (vessel area minus lumen area) and plaque burden ([plaque area/vessel area] $\times 100$ ). For the radiofrequency-IVUS analyses, four tissue components (necrotic core-red; dense calcium-white; fibrous-dark green; and fibrofatty-light green) were identified with autoregressive classification systems. Each individual tissue component was quantified and color-coded in IVUS cross sections, as previously described [7, 15].

Lesions were classified by 2 experienced and independent observers, blinded to FFR data, based on plaque composition in 3 consecutive frames within the lesion, as previously described [16]: pathological intimal thickening (PIT), thin-cap fibroatheroma (TCFA), calcified fibroatheroma (CAFA), thickcapped fibroatheroma (ThFA), calcified thick-cap fibroatheroma (CATHFA), fibrotic plaque and fibrocalcific plaque [17, 18]. In case of disagreement, a consensus was reached between the two observers. PIT consisted of mainly a mixture of fibrous and fibrofatty tissue plaque with $<10 \%$ confluent necrotic core and $<10 \%$ confluent dense calcium. TCFA was a fibroatheroma without evidence of a fibrous cap: $>10 \%$ confluent necrotic core with $>30^{\circ}$ necrotic core in contact with the lumen. Calcified fibroatheroma was a fibroatheroma with $>10 \%$ confluent dense calcium. ThFA was a fibroatheroma $(>10 \%$ of confluent necrotic core) with a definable fibrous cap. CATHFA was a ThFA with $>10 \%$ confluent dense calcium. Fibrotic plaque (FT) consisted of mainly fibrous tissue with $<10 \%$ confluent necrotic core, $<15 \%$ fibrofatty tissue and $<10 \%$ confluent dense calcium. Fibrocalcific plaque (FC) was composed of nearly all fibrous tissue and dense calcium with $<10 \%$ confluent necrotic core. All the plaques with $>10 \%$ of necrotic core were also classified as NC-rich plaques. 
FFR evaluation

The FFR evaluation was done according to the current guidelines [12, 13]. The FFR was measured with a coronary pressure guidewire (Radi, St.Jude Medical, Uppsala, Sweden) at maximal hyperemia induced by intravenous adenosine, administered at $140 \mu \mathrm{g} / \mathrm{kg} / \mathrm{min}$ through a periferical vein. FFR is calculated as the mean distal coronary pressure (measured with the pressure wire) divided by the mean aortic pressure (measured simultaneously with the guiding catheter) during maximal hyperemia [19]. In the case of diffuse atherosclerosis punctuated by focal areas of more severe stenosis, or in the case of more than one stenosis within the same artery, pressure pullback recordings during hyperemia were performed as described previously [13, 20]. In addition, whenever another significant lesion was detected within the same vessel it was recommended by protocol that the FFR measurements should be performed after this lesion had been treated.

\section{Statistical analysis}

Categorical variables were expressed as counts and percentage. Group differences of categorical variables were compared using chi-square or fisher-exact test, as appropriate. Continuous variables were expressed as mean \pm standard deviation (SD). The normal distribution of the variables was explored by Kolgomorov-Smirnov test. As the variables were not normally distributed, comparison between groups was done by non parametric tests. A $P$ value of $<0.05$ was considered significant, and all tests were two-tailed. Data were analyzed with SPSS version 16.0 software (SPSS Inc., Chicago, IL).

\section{Results}

Baseline clinical and angiographic characteristics

Fifty-five consecutive patients were enrolled in the study. Table 1 shows their clinical and angiographic characteristics. All the patients included had only one-vessel disease, that was investigated by FFR and IVUS-VH analyses. In particular 17 out of these patients $(31 \%)$ showed a FFR $\leq 0.80$ and 13 patients (23\%) received stent implantation on the lesion evaluated by FFR. The remaining 4 patients did not receive any treatment for the following reasons: the minimum lumen area by IVUS was $>4 \mathrm{~mm}^{2}$ in 3 patients and the FFR was 0.79 in 1 patient. The 38 patients with a FFR $\geq 0.80$ did not receive any revascularization treatment and were treated by medical therapy.

QCA analysis confirmed that all the lesions included in the analysis were angiographically moderate lesions ( $46 \%$ mean stenosis), for which the FFR evaluation is indicated according to guidelines. Patients with a FFR $\geq 0.80$ exhibited higher RVD and MLD than those patients with a FFR $\leq 0.80$ (Table 1).

IVUS geometrical analysis (Table 2)

Plaque burden was slightly larger for those lesions with a FFR $\leq 0.80(54.6 \pm 0.7 \%$ vs. $51.7 \pm 0.7 \%$ $P=0.1)$ accompanied with a reduction in lumen area $\left(7.1 \pm 1.8 \mathrm{~mm}^{2}\right.$ vs. $\left.7.9 \pm 2.4 \mathrm{~mm}^{2}, P=0.1\right)$ and without expansion of the vessel area as compared to their counterparts $\left(16.0 \pm 5.0 \mathrm{~mm}^{2}\right.$ vs. $16.5 \pm 4.4$ $\left.\mathrm{mm}^{2}, P=0.4\right)$. Minimum lumen area was lower for those lesions with a FFR $\leq 0.80$ than those with a FFR $>0.80(P=0.07)$.

\section{IVUS-VH analysis}

Table 2 shows the compositional IVUS-VH data. Plaques with FFR $\leq 0.80$ showed higher relative content of fibrofatty tissue $(P=0.02)$ and a trend towards a lower relative content of necrotic core $(P=0.08)$ compared to plaques with FFR $>0.80$.

Plaque classification yielded good concordance between the two observers $(\kappa=0.85)$. Overall, we found 9 PIT, 2 FC, 7 FA, 6 CaFA, 9 TCFA and 22 CaTCFA (Fig. 1). No difference was found in the distribution of VH-plaque type between the two groups (Fig. 2). NC-rich plaque distribution was also not different between groups ( $82 \%$ in FFR $\leq 0.80$ vs. $79 \%$ in FFR $>0.80, P=0.5$ ).

\section{Discussion}

The major finding of this analysis is that, although larger plaques are associated with FFR $\leq 0.80$, VHplaque composition and VH-plaque type are not 
Table 1 Clinical and angiographic characteristics

\begin{tabular}{|c|c|c|c|c|}
\hline & $\begin{array}{l}\text { Patients }(n=55) \\
\text { Lesions }(n=55)\end{array}$ & $\begin{array}{l}\text { FFR }>0.80 \\
(38 \text { patients })\end{array}$ & $\begin{array}{l}\text { FFR } \leq 0.80 \\
(17 \text { patients })\end{array}$ & $P$ value \\
\hline Age (years) & $61 \pm 10$ & $61 \pm 9$ & $60 \pm 12$ & 0.24 \\
\hline \multicolumn{5}{|l|}{ Mean $\pm \operatorname{SD}(n)$} \\
\hline Men $(\%)$ & 83 & 81 & 88 & 0.70 \\
\hline Smokers $(\%)$ & 56 & 55 & 58 & 1.00 \\
\hline Diabetes $(\%)$ & 12 & 15 & 5 & 0.41 \\
\hline Hypertension requiring medication $(\%)$ & 63 & 65 & 58 & 0.76 \\
\hline Hyperlipidaemia requiring medication (\%) & 69 & 68 & 70 & 1.00 \\
\hline Stable angina $(\%)$ & 69 & 71 & 65 & 0.75 \\
\hline Unstable angina $(\%)$ & 30 & 29 & 35 & 0.63 \\
\hline Target vessel $(\%)$ & & & & 0.98 \\
\hline Left anterior descending & 65 & 65 & 64 & \\
\hline Left circumflex & 16 & 15 & 18 & \\
\hline Right coronary artery & 18 & 20 & 18 & \\
\hline \multicolumn{5}{|l|}{ QCA analysis } \\
\hline $\operatorname{MLD}(\mathrm{mm})$ & $1.66 \pm 0.37$ & $1.76 \pm 0.34$ & $1.43 \pm 0.34$ & 0.03 \\
\hline RVD (mm) & $3.14 \pm 0.52$ & $3.25 \pm 0.54$ & $2.90 \pm 0.39$ & 0.03 \\
\hline$\%$ stenosis & $46.1 \pm 0.9$ & $45.2 \pm 0.8$ & $49.0 \pm 0.1$ & 0.16 \\
\hline FFR & $0.84 \pm 0.08$ & NA & NA & NA \\
\hline
\end{tabular}

$S D$ standard deviation, $Q C A$ quantitative coronary angiography, $M L D$ minimum lumen diameter, $R V D$ reference vessel diameter, FFR fractional flow reserve

different between lesions with FFR more or equal/ less than 0.80 .

From previous studies it is known that patients, who have lesions with a FFR $>0.80$, if optimally treated with medication, have a good prognosis up to 5-years [4]. However, the MACE rate of these patients may range from 8 to $21 \%$ [21-25]. We set out this exploratory study to investigate whether plaque composition could be one of the reasons to explain this occurrence of events if these lesions are left untreated, based on FFR findings. Interestingly, QCA already discriminates in our analysis the lesions with a FFR $\leq 0.80$ which have smaller MLD and RVD compared with lesions with a FFR $\geq 0.80$. However, it appears that although FFR $\leq 0.80$ lesions are more stenotic and have larger size, they do not differ in composition from the ones with FFR $>0.80$ and left untreated. Rogers et al. [26] demonstrated a heterogeneous VH-plaque type morphology with prevalence of TCFA in FFR-negative lesions. In our study, comparing FFR negative and positive lesions, we found that the relative content of $\mathrm{NC}$ seems to be higher in lesions with a FFR $>0.80$
$(P=0.08)$. This could be a possible explanation of MACE for those patients with angiographically intermediate lesions, left untreated as no functionally significant by FFR $(>0.80)$ [21]. In addition, lesions with FFR $\leq 0.80$ exhibited higher fibrofatty tissue content than those lesions with FFR $\geq 0.80$ $(P=0.02)$. This tissue, corresponding to lipids without necrosis, is namely present in PIT, that have been shown able to evolve in VH-fibroatheroma [27].

From pathological studies it is known that specific coronary plaques characteristics, such thin fibrous cap, paucity of smooth muscle cells, heavy inflammatory infiltration of the cap and large necrotic cores correlate with fatal ischemic events [28]. The recent PROSPECT trial has also shown that thin-capped fibroatheroma, identified by IVUS-VH, is a strong independent predictor of events at 3-year follow-up [11]. Angiographic studies before and after myocardial infarction showed that pre-existing lesions at the sites of myocardial infarction are not usually accompanied by hemodinamically significant stenosis [29]. In sudden coronary death, at least $50 \%$ of the thrombosis occurred at lesion sites with $\leq 50 \%$ 
Table 2 IVUS-VH data

Data are expressed as mean \pm standard deviation. $F F R$ fractional flow reserve, $P I T$ pathological intimal thickening, $F C$ fibrocalcific plaque, $F A$ fibroatheroma,

$C a F A$ calcified

fibroatheroma, TCFA thin-

cap fibroatheroma, CaTCFA

calcified thin-cap

fibroatheroma

\begin{tabular}{llll}
\hline & $\begin{array}{l}\text { FFR }>0.80 \\
(n=38 \text { lesions })\end{array}$ & $\begin{array}{l}\text { FFR } \leq 0.80 \\
(n=17 \text { lesions })\end{array}$ & $P$ value \\
\hline IVUS-VH data & & & \\
Mean plaque area $\left(\mathrm{mm}^{2}\right)$ & $8.6 \pm 2.6$ & $8.9 \pm 3.5$ & 0.8 \\
Plaque burden $(\%)$ & $51.7 \pm 0.7$ & $54.6 \pm 0.7$ & 0.1 \\
Mean lumen area $\left(\mathrm{mm}^{2}\right)$ & $7.9 \pm 2.4$ & $7.1 \pm 1.8$ & 0.1 \\
Minimum lumen area $\left(\mathrm{mm}^{2}\right)$ & $5.6 \pm 2.3$ & $4.6 \pm 1.2$ & 0.07 \\
Mean vessel area $\left(\mathrm{mm}^{2}\right)$ & $16.5 \pm 4.4$ & $16.0 \pm 5.0$ & 0.4 \\
Fibrous tissue $\left(\mathrm{mm}^{2}\right)$ & $2.7 \pm 1.4$ & $3.0 \pm 1.8$ & 0.6 \\
Fibrous tissue $(\%)$ & $54.5 \pm 10.7$ & $57.3 \pm 6.7$ & 0.2 \\
Fibrofatty tissue $\left(\mathrm{mm}^{2}\right)$ & $0.8 \pm 0.8$ & $1.2 \pm 1.1$ & 0.07 \\
Fibrofatty tissue $(\%)$ & $15.1 \pm 11.1$ & $21.5 \pm 10.8$ & 0.02 \\
Necrotic core tissue $\left(\mathrm{mm}^{2}\right)$ & $0.9 \pm 0.5$ & $0.7 \pm 0.4$ & 0.2 \\
Necrotic core tissue $(\%)$ & $19.2 \pm 10.2$ & $14.2 \pm 8.0$ & 0.08 \\
Dense calcium $\left(\mathrm{mm}^{2}\right)$ & $0.5 \pm 0.4$ & $0.3 \pm 0.3$ & 0.1 \\
Dense calcium $(\%)$ & $11.0 \pm 8.3$ & $6.8 \pm 4.8$ & 0.1 \\
VH plaque distribution & & & 0.7 \\
PIT, $n(\%)$ & $6(15)$ & $3(17)$ & \\
FC, $n(\%)$ & $2(8)$ & $0(0)$ & \\
FA, $n(\%)$ & $4(10)$ & $3(17)$ & \\
CaFA, $n(\%)$ & $5(13)$ & $1(8)$ & \\
TCFA, $n(\%)$ & $6(15)$ & $7(41)$ & \\
CaTCFA, $n(\%)$ & $15(39)$ & & \\
\hline
\end{tabular}

angiographic diameter reduction [30]. However, we cannot elucidate from our study whether the lesions with FFR $>0.80$ that are NC rich (77\% of them) are the ones associated with the presence of clinical events at follow-up. This hypothesis needs further exploration in a larger prospective study.

On the other side, Kubo et al. [27] showed recently that there are various possible pathways in the evolution and stabilization of NC-rich plaques. At 12-month follow-up they found that most of the NCrich plaques healed or stabilized. The mechanism of healing is not well established. The transformation of hematoma and/or thrombus into fibrous muscular tissue and the formation or increase in thickness of the fibrous cap could lead to plaque stabilization [31]. Some studies have proposed that a silent rupture or a plaque rupture proximal to a lesion might lead to mural thrombus and subsequent formation of a fibrotic cap over the TCFA [32, 33]. This could be the natural evolution of the NC-rich plaques for lesions with a FFR more than 0.80 , as the good prognosis of these patients. In addition, it is noteworthy to consider that a large minimum lumen area could also favor a silent NC-rich plaque rupture, allowing a coronary flow sufficient to avoid a clinical event. In our study, we found, indeed, a lower minimal lumen area in FFR $\leq 0.80$ lesions as compared to FFR $>0.80$ lesions. This hypothesis also would need further exploration in a larger prospective study.

Finally, it is important to highlight that IVUS-VH and FFR are two different ways to evaluate the significance of a coronary plaque. While FFR is a standardized method evaluating the functional significance of an intermediate coronary stenosis, IVUS$\mathrm{VH}$ analysis provides information on the plaque size and on its tissue characterization through its backscattering signal. As virtual histology is a soundbased imaging modality using the radiofrequency data to compute 4 different tissue types, it suffers from all limitations as any other ultrasound-derived techniques. While the use of FFR to decide the percutaneous treatment of a coronary lesion has been widely described and correlated with long-term prognosis [13, 34], the use of $\mathrm{VH}$ to decide a percutaneous treatment of a coronary plaque is not 

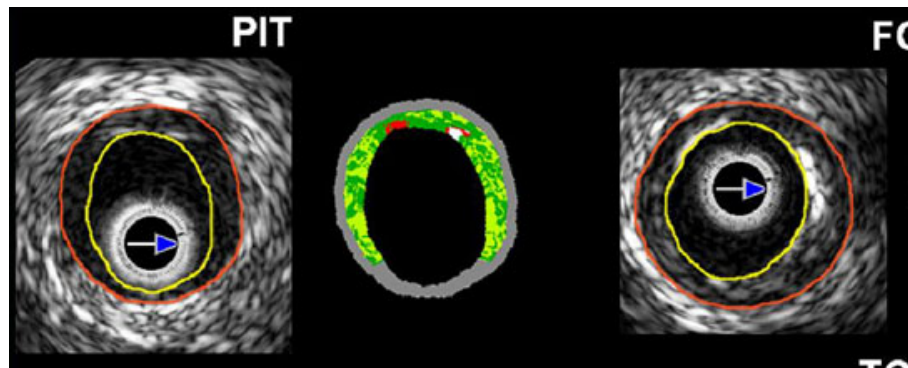

FC
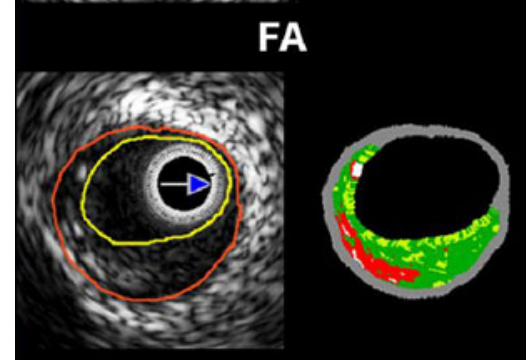

CaFA

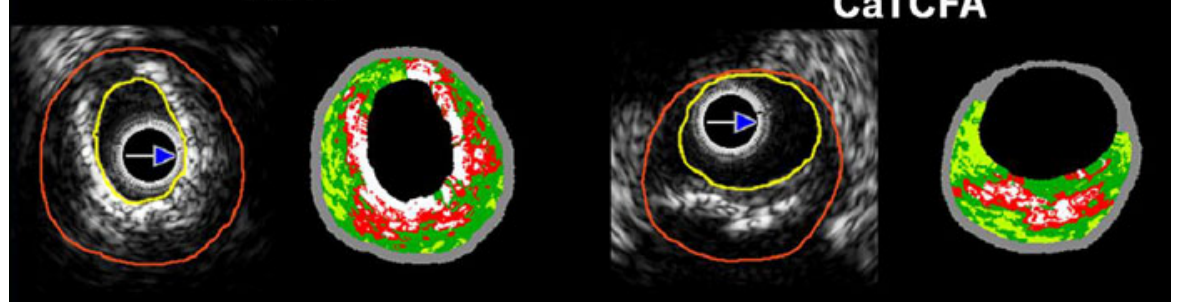

Fig. 1 Examples of various type of VH-plaque found in the analysis with the corresponding IVUS appearance. Lumen contour (yellow line) and vessel contour (red line) are shown. In the VH images, necrotic core is coded as red, dense calcium as white, fibrous tissue as dark green and fibrofatty tissue as light green. PIT pathological intimal thickening, $F C$ fibrocalcific plaque, $F A$ fibroatheroma, TCFA thin-cap fibroatheroma, CaFA calcified fibroatheroma, CaTCFA calcified thin-cap fibroatheroma
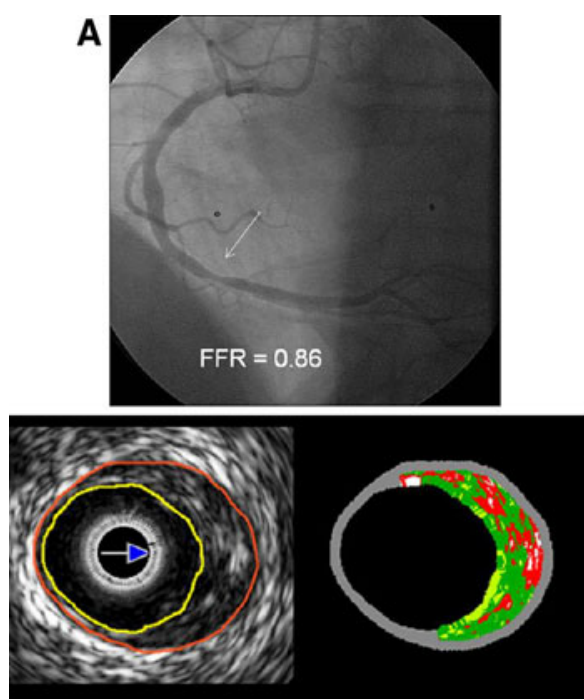

\section{B}
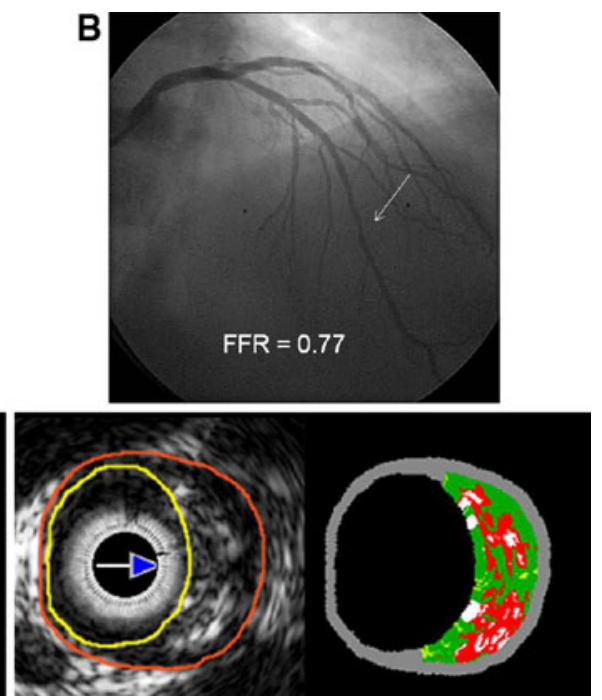

Fig. 2 Examples of two different lesions (white arrows) with a FFR $>0.80$ (panel A) and $\leq 0.80$ (panel B), both showing a FA VHplaque type. In the IVUS images red and yellow contours indicate vessel and lumen contours, respectively 
well investigated yet. The SECRITT-I trial is ongoing to test the efficacy of preventive treatment of a NCrich plaque with a self-expanding stent, that allows the formation of a fibrous cap [35].

\section{Limitations}

This is a registry study and included a small number of patients. No clinical or angiographic follow-up are available. Our findings only focused on ambiguous/ equivocal lesions were the use of FFR was considered of value in the clinical decision process. Whether other lesions causing less significant stenosis have different composition as compared with hemodinamically significant lesions will require additional studies.

\section{Conclusions}

Coronary lesions with FFR more or less than 0.80 are not different in terms of plaque composition and virtual histology plaque types from their counterparts. The hypothesis of whether a preventive treatment might be required for those patients who have a NCrich plaque with FFR $>0.80$ needs to be further explored.

Conflict of interest None of the authors have any conflict of interest to declare.

\section{References}

1. Shaw LJ, Berman DS, Maron DJ, Mancini GB, Hayes SW, Hartigan PM, Weintraub WS, O'Rourke RA, Dada M, Spertus JA, Chaitman BR, Friedman J, Slomka P, Heller GV, Germano G, Gosselin G, Berger P, Kostuk WJ, Schwartz RG, Knudtson M, Veledar E, Bates ER, McCallister B, Teo KK, Boden WE (2008) Optimal medical therapy with or without percutaneous coronary intervention to reduce ischemic burden: results from the clinical outcomes utilizing revascularization and aggressive drug evaluation (courage) trial nuclear substudy. Circulation 117(10): 1283-1291. doi:10.1161/CIRCULATIONAHA.107.743963

2. Erne P, Schoenenberger AW, Burckhardt D, Zuber M, Kiowski W, Buser PT, Dubach P, Resink TJ, Pfisterer M (2007) Effects of percutaneous coronary interventions in silent ischemia after myocardial infarction: the swissi ii randomized controlled trial. JAMA 297(18):1985-1991. doi:10.1001/jama.297.18.1985

3. Boden WE, O'Rourke RA, Teo KK, Hartigan PM, Maron DJ, Kostuk WJ, Knudtson M, Dada M, Casperson P, Harris CL, Chaitman BR, Shaw L, Gosselin G, Nawaz S, Title LM, Gau G, Blaustein AS, Booth DC, Bates ER, Spertus
JA, Berman DS, Mancini GB, Weintraub WS (2007) Optimal medical therapy with or without pci for stable coronary disease. N Engl J Med 356(15):1503-1516. doi: 10.1056/NEJMoa070829

4. Pijls NH, van Schaardenburgh P, Manoharan G, Boersma E, Bech JW, van't Veer M, Bar F, Hoorntje J, Koolen J, Wijns W, de Bruyne B (2007) Percutaneous coronary intervention of functionally nonsignificant stenosis: 5-year follow-up of the defer study. J Am Coll Cardiol 49(21):2105-2111. doi:10.1016/j.jacc.2007.01.087

5. Pijls NH, De Bruyne B, Peels K, Van Der Voort PH, Bonnier HJ, Bartunek JKJJ, Koolen JJ (1996) Measurement of fractional flow reserve to assess the functional severity of coronary-artery stenoses. N Engl J Med 334(26):17031708. doi:10.1056/NEJM199606273342604

6. Pijls NH, Van Gelder B, Van der Voort P, Peels K, Bracke FA, Bonnier HJ, el Gamal MI (1995) Fractional flow reserve. A useful index to evaluate the influence of an epicardial coronary stenosis on myocardial blood flow. Circulation 92(11):3183-3193

7. Nair A, Kuban BD, Tuzcu EM, Schoenhagen P, Nissen SE, Vince DG (2002) Coronary plaque classification with intravascular ultrasound radiofrequency data analysis. Circulation 106(17):2200-2206

8. Nair A, Margolis MP, Kuban BD, Vince DG (2007) Automated coronary plaque characterisation with intravascular ultrasound backscatter: ex vivo validation. EuroIntervention 3(1):113-120

9. Nasu K, Tsuchikane E, Katoh O, Vince DG, Virmani R, Surmely JF, Murata A, Takeda Y, Ito T, Ehara M, Matsubara T, Terashima M, Suzuki T (2006) Accuracy of in vivo coronary plaque morphology assessment: a validation study of in vivo virtual histology compared with in vitro histopathology. J Am Coll Cardiol 47(12):2405-2412. doi: 10.1016/j.jacc.2006.02.044

10. Stary HC, Chandler AB, Dinsmore RE, Fuster V, Glagov S, Insull W Jr, Rosenfeld ME, Schwartz CJ, Wagner WD, Wissler RW (1995) A definition of advanced types of atherosclerotic lesions and a histological classification of atherosclerosis. A report from the committee on vascular lesions of the council on arteriosclerosis, American heart association. Arterioscler Thromb Vasc Biol 15(9):15121531

11. Stone GW, Maehara A, Lansky AJ, de Bruyne B, Cristea E, Mintz GS, Mehran R, McPherson J, Farhat N, Marso SP, Parise H, Templin B, White R, Zhang Z, Serruys PW, PROSPECT Investigators (2011) A prospective naturalhistory study of coronary atherosclerosis. N Engl J Med 364(3):226-235

12. De Bruyne B, Pijls NH, Bartunek J, Kulecki K, Bech JW, De Winter H, Van Crombrugge P, Heyndrickx GR, Wijns W (2001) Fractional flow reserve in patients with prior myocardial infarction. Circulation 104(2):157-162

13. Tonino PA, De Bruyne B, Pijls NH, Siebert U, Ikeno F, van' t Veer M, Klauss V, Manoharan G, Engstrom T, Oldroyd KG, Ver Lee PN, MacCarthy PA, Fearon WF (2009) Fractional flow reserve versus angiography for guiding percutaneous coronary intervention. $\mathrm{N}$ Engl J Med 360(3):213-224. doi:10.1056/NEJMoa0807611

14. Reiber JH, Serruys PW (1991) Quantitative coronary angiography: methodologies. Quantitative Coronary 
Angiography Dordrecht, vol 98. Kluwer Academic Publichers, The Netherlands, p 102

15. Serruys PW, Ormiston JA, Onuma Y, Regar E, Gonzalo N, Garcia-Garcia HM, Nieman K, Bruining N, Dorange C, Miquel-Hebert K, Veldhof S, Webster M, Thuesen L, Dudek D (2009) A bioabsorbable everolimus-eluting coronary stent system (absorb): 2-year outcomes and results from multiple imaging methods. Lancet 373(9667):897910. doi:10.1016/S0140-6736(09)60325-1

16. Garcia-Garcia HM, Mintz GS, Lerman A, Vince DG, Margolis MP, van Es GA, Morel MA, Nair A, Virmani R, Burke AP, Stone GW, Serruys PW (2009) Tissue characterisation using intravascular radiofrequency data analysis: recommendations for acquisition, analysis, interpretation and reporting. EuroIntervention 5(2):177-189

17. Rodriguez-Granillo GA, Garcia-Garcia HM, Mc Fadden EP, Valgimigli M, Aoki J, de Feyter P, Serruys PW (2005) In vivo intravascular ultrasound-derived thin-cap fibroatheroma detection using ultrasound radiofrequency data analysis. J Am Coll Cardiol 46(11):2038-2042. doi:10. 1016/j.jacc.2005.07.064

18. Konig A, Margolis MP, Virmani R, Holmes D, Klauss V (2008) Technology insight: in vivo coronary plaque classification by intravascular ultrasonography radiofrequency analysis. Nat Clin Pract Cardiovasc Med 5(4):219-229. doi:10.1038/ncpcardio1123

19. Pijls NH, van Son JA, Kirkeeide RL, De Bruyne B, Gould KL (1993) Experimental basis of determining maximum coronary, myocardial, and collateral blood flow by pressure measurements for assessing functional stenosis severity before and after percutaneous transluminal coronary angioplasty. Circulation 87(4):1354-1367

20. Pijls NH (2004) Optimum guidance of complex pci by coronary pressure measurement. Heart 90(9):1085-1093. doi:10.1136/hrt.2003.032151

21. Bech GJ, De Bruyne B, Pijls NH, de Muinck ED, Hoorntje JC, Escaned J, Stella PR, Boersma E, Bartunek J, Koolen JJ, Wijns W (2001) Fractional flow reserve to determine the appropriateness of angioplasty in moderate coronary stenosis: a randomized trial. Circulation 103(24): 2928-2934

22. Leesar MA, Abdul-Baki T, Yalamanchili V, Hakim J, Kern M (2003) Conflicting functional assessment of stenoses in patients with previous myocardial infarction. Catheter Cardiovasc Interv 59(4):489-495. doi:10.1002/ccd.10550

23. Hernandez Garcia MJ, Alonso-Briales JH, Jimenez-Navarro M, Gomez-Doblas JJ, Rodriguez Bailon I, de Teresa Galvan E (2001) Clinical management of patients with coronary syndromes and negative fractional flow reserve findings. J Interv Cardiol 14(5):505-509

24. Bech GJ, Pijls NH, De Bruyne B, Peels KH, Michels HR, Bonnier HJ, Koolen JJ (1999) Usefulness of fractional flow reserve to predict clinical outcome after balloon angioplasty. Circulation 99(7):883-888

25. Kern MJ, Lerman A, Bech JW, De Bruyne B, Eeckhout E, Fearon WF, Higano ST, Lim MJ, Meuwissen M, Piek JJ, Pijls NH, Siebes M, Spaan JA (2006) Physiological assessment of coronary artery disease in the cardiac catheterization laboratory: a scientific statement from the American heart association committee on diagnostic and interventional cardiac catheterization, council on clinical cardiology. Circulation 114(12):1321-1341. doi:10.1161/ CIRCULATIONAHA.106.177276

26. Rogers JH, Wegelin J, Harder K, Valente R, Low R (2006) Assessment of ffr-negative intermediate coronary artery stenoses by spectral analysis of the radiofrequency intravascular ultrasound signal. J Invasive Cardiol 18(10): 448-453

27. Kubo T, Maehara A, Mintz GS, Doi H, Tsujita K, Choi SY, Katoh O, Nasu K, Koenig A, Pieper M, Rogers JH, Wijns W, Bose D, Margolis MP, Moses JW, Stone GW, Leon MB (2010) The dynamic nature of coronary artery lesion morphology assessed by serial virtual histology intravascular ultrasound tissue characterization. J Am Coll Cardiol 55 (15):1590-1597. doi:10.1016/j.jacc.2009.07.078

28. Virmani R, Kolodgie FD, Burke AP, Farb A, Schwartz SM (2000) Lessons from sudden coronary death: a comprehensive morphological classification scheme for atherosclerotic lesions. Arterioscler Thromb Vasc Biol 20(5): 1262-1275

29. de Feyter PJ, Ozaki Y, Baptista J, Escaned J, Di Mario C, de Jaegere PP, Serruys PW, Roelandt JR (1995) Ischemiarelated lesion characteristics in patients with stable or unstable angina. A study with intracoronary angioscopy and ultrasound. Circulation 92(6):1408-1413

30. Farb A, Tang AL, Burke AP, Sessums L, Liang Y, Virmani R (1995) Sudden coronary death. Frequency of active coronary lesions, inactive coronary lesions, and myocardial infarction. Circulation 92(7):1701-1709

31. Stary HC (2000) Natural history and histological classification of atherosclerotic lesions: an update. Arterioscler Thromb Vasc Biol 20(5):1177-1178

32. Virmani R, Burke AP, Farb A, Kolodgie FD (2006) Pathology of the vulnerable plaque. J Am Coll Cardiol 47(8 Suppl):C13-C18. doi:10.1016/j.jacc.2005.10.065

33. Burke AP, Kolodgie FD, Farb A, Weber DK, Malcom GT, Smialek J, Virmani R (2001) Healed plaque ruptures and sudden coronary death: evidence that subclinical rupture has a role in plaque progression. Circulation 103(7): 934-940

34. Pijls NH, Fearon WF, Tonino PA, Siebert U, Ikeno F, Bornschein B, van't Veer M, Klauss V, Manoharan G, Engstrom T, Oldroyd KG, Ver Lee PN, MacCarthy PA, De Bruyne B (2010) Fractional flow reserve versus angiography for guiding percutaneous coronary intervention in patients with multivessel coronary artery disease: 2-year follow-up of the fame (fractional flow reserve versus angiography for multivessel evaluation) study. J Am Coll Cardiol 56 (3):177-184. doi:10.1016/j.jacc.2010.04.012

35. Ramcharitar S, Gonzalo N, van Geuns RJ, Garcia-Garcia HM, Wykrzykowska JJ, Ligthart JM, Regar E, Serruys PW (2009) First case of stenting of a vulnerable plaque in the secritt i trial-the dawn of a new era? Nat Rev Cardiol 6(5):374-378. doi:10.1038/nrcardio.2009.34 